\title{
Emissions from Fossil Fuels Produced on US Federal Lands Present Opportunities for Climate Mitigation
}

Nathan Ratledge ( $\square$ ratledge@stanford.edu )

Stanford University https://orcid.org/0000-0002-4529-2225

Laura Zachary

Apogee Economics and Policy

Chase Huntley

The Wilderness Society

\section{Research Article}

Keywords: climate change, energy policy, climate policy, fossil fuels, public lands

Posted Date: March 10th, 2021

DOl: https://doi.org/10.21203/rs.3.rs-256921/v1

License: (c) (1) This work is licensed under a Creative Commons Attribution 4.0 International License.

Read Full License 
$1 \quad$ Title

\section{Emissions from Fossil Fuels Produced on US Federal Lands Present}

3 Opportunities for Climate Mitigation

4

Author Information

Nathan Ratledge, Emmet Interdisciplinary Program in Environment and Resources, Stanford University, Palo Alto, CA, USA (ratledge@stanford.edu). ORCID identifier: 0000-0002-4529-2225

Laura Zachary, Co-director, Apogee Economics and Policy, Washington, D.C., USA (laura@apogeeep.com). ORCID identifier: 0000-0002-0106-5303

Chase Huntley, Interim Deputy Vice President, Energy \& Climate Program, The Wilderness Society, Washington, D.C., USA (chuntley@tws.org). ORCID identifier: 0000-0003-4938-5151

Abstract

Between 2005 and 2019 emissions from fossil fuels produced on federal lands and waters accounted for nearly a quarter of annual US energy emissions, roughly 1,400 million metric tons of carbon dioxide equivalent per year. Despite their magnitude, emissions stemming from federal lands energy production have not historically featured in US climate policy. To better understand their future role in the US's emissions profile, we model coal, oil and natural gas production on federal lands and waters to 2030, and then calculate associated lifecycle climate emissions. We estimate that total emissions from fossil fuels produced on federal lands and waters decline $28 \%$ below 2010 levels by 2030 , which falls well short of the $45 \%$ global reduction target needed to be consistent with avoiding a $1.5^{\circ} \mathrm{C}$ temperature rise. The Biden-Harris administration will likely need to pursue a suite of actions if they hope to bring federal emissions in line with ambitious climate targets. Several options, including a carbon adder on royalties for new federal leases, can be quickly enacted without Congressional approval.

Keywords

climate change; energy policy; climate policy; fossil fuels; public lands

\section{Declarations}

Funding (This work was partially funded by The Wilderness Society) Conflicts of interest/Competing interests (Chase Huntley is a Vice President at The Wilderness Society, a public lands conservation organization.) Availability of data and material (Data used in Figure 1 is available upon request.) Code availability (Figure 1 code is available upon request.) 
Authors' contributions (Nathan Ratledge collected data, performed the production modeling and wrote the paper. Laura Zachary collected data, performed emissions

Word count (excluding tables and figures): Abstract $=167$; Main text $=2,047$; references $=569$.

The US government is one of the world's largest energy asset managers, responsible for overseeing fossil fuel development on over 2.4 billion acres of onshore and offshore subsurface mineral rights (BLM 2020; BOEM 2020). Oil, gas, and coal extracted from federal public lands and waters (hereinafter referred to as "federal lands") between 2005 and 2019 contributed an average 1,408 million metric tons of carbon dioxide equivalent $\left(\mathrm{MMTCO}_{2} \mathrm{e}\right)$ per year, $25 \%$ of annual US energy emissions. Despite their sizeable contribution to the US's emissions profile, there is little research on future emissions stemming from federal lands fuel production. Estimating these future trends is critical for developing domestic climate and energy policy, particularly because federal lands production can be regulated directly by the Department of the Interior without Congressional approval (Leshy 2019; Pleune et al. 2020; Krupnick et al. 2016).

While the US government has acknowledged the large share of US emissions stemming from federal fossil fuels, federal agencies have failed to track federal lands emissions in any comprehensive, annually updated, or public way. In their one-time 2018 report, the United States Geological Survey (USGS) estimated that lifecycle emissions from coal, oil and natural gas produced on federal lands and waters accounted for $1,279 \mathrm{MMTCO}_{2} \mathrm{e}$ in $2014,22.4 \%$ of US energy emissions (Merrill et al. 2018). The USGS report estimated federal lands emissions for 2005 to 2014 and the report established a methodology that was meant to create a publicly available database of estimated greenhouse gas (GHG) emissions associated with fossil fuels from federal lands that would be updated every year. Under the Trump administration, this annually updated database of federal lands emissions never happened. Our research helps to fill this gap and also provides a forward-looking emissions estimate. This work also helps to inform the Biden-Harris administration, who ordered a pause to new oil and gas leases on public lands and offshore waters pending a review to ensure that management of public resources is in line with national climate goals (Exec. Order No. 14008,2021$)$.

Specifically, we extend the USGS's work (Merrill et al. 2018) by updating historic federal emissions calculations thru 2019. We then impute future federal lands production to 2030 and estimate associated, lifecycle $\mathrm{CO}_{2}$ e emissions. These estimates provide a 
novel, comprehensive assessment of near-term federal lands energy emissions and indicate that, absent a change in policy or market shift, emissions from federal lands' energy production will not play a proportionate role in meeting stringent climate targets, nor demonstrate a leadership position for the federal government.

First, we aggregate historic coal, oil and gas production on federal lands from the Office of Natural Resource Revenue. We then create an emissions profile to 2019 for each of the five fuel sources, based on the methodology used in the Environmental Protection Agency's Inventory of U.S. Greenhouse Gas Emissions and Sinks: 1990-2018 (hereon EPA Inventory), which includes upstream, midstream and downstream emissions (US

We combine forecasts from the reference case scenario in the EIA's Annual Energy Outlook 2020 (US EIA 2020a) with the historic ONRR data to create panel data to 2030. Using the combined ONRR and EIA data as control variables, we predict future onshore coal, oil and gas production to 2030 via a regularized regression method, specifically synthetic controls with elastic net (Doudchenko and Imbens 2016). We combine our predicted onshore coal, oil and gas estimates with EIA's offshore oil and gas projections to obtain total supply estimates from 2020 to 2030 . Finally, we calculate $\mathrm{CO}_{2} \mathrm{e}$ emissions for our predicted figures to obtain a future federal lands emissions profile.

We find historic emissions stemming from federal fuels (2005-2019) averaged over $1,408 \mathrm{MMTCO}_{2} \mathrm{e}$ annually, nearly $25 \%$ of total US energy emissions. For perspective, if federal fuels were a country, its emissions in 2018 would be ranked 6th - just below Japan and tied with Brazil. ${ }^{1}$ Over this $15-y e a r$ period, federal coal emissions fell $38 \%$ and natural gas emissions dropped by $37 \%$. Federal oil emissions, however, rose by $60 \%$ due to onshore and offshore production growth. The estimated costs to society of the lifecycle emissions stemming from fossil fuel development on US federal lands and waters between 2005 to 2019 averaged $\$ 58$ billion per year in 2020 dollars. Altogether, federal emissions for years 2005 thru 2019 carry an estimated cumulative cost of $\$ 864$ billion.

Looking forward, our model finds modest changes to total future federal energy production between 2019 and 2030, decreasing by just 4\%. Given the higher carbon intensities of coal and oil compared to gas, changes by fuel type are of greater note from an emissions perspective. Coal continues its decline, losing $22 \%$ of federal production by 2030 . Declines in onshore gas production are partially offset by increases in offshore gas, $-21 \%$ and $+15 \%$ respectively. Both onshore and offshore oil

\footnotetext{
${ }^{1}$ Authors compare lifecycle emissions of fossil fuels extracted from public lands and waters in 2018 to country GHG emissions excluding land use change reported by Oliver and Peters (2019).
} 


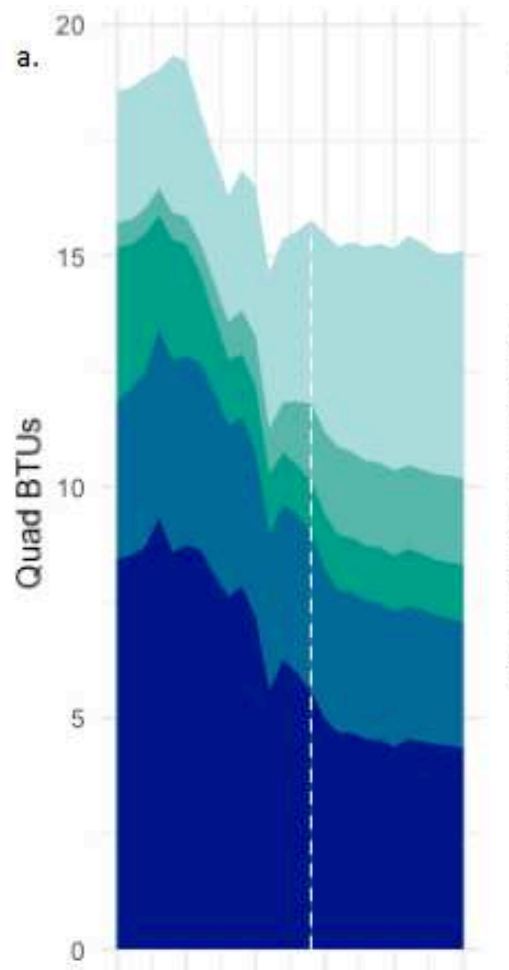

124 $\mathrm{MMTCO}_{2} \mathrm{e}$.
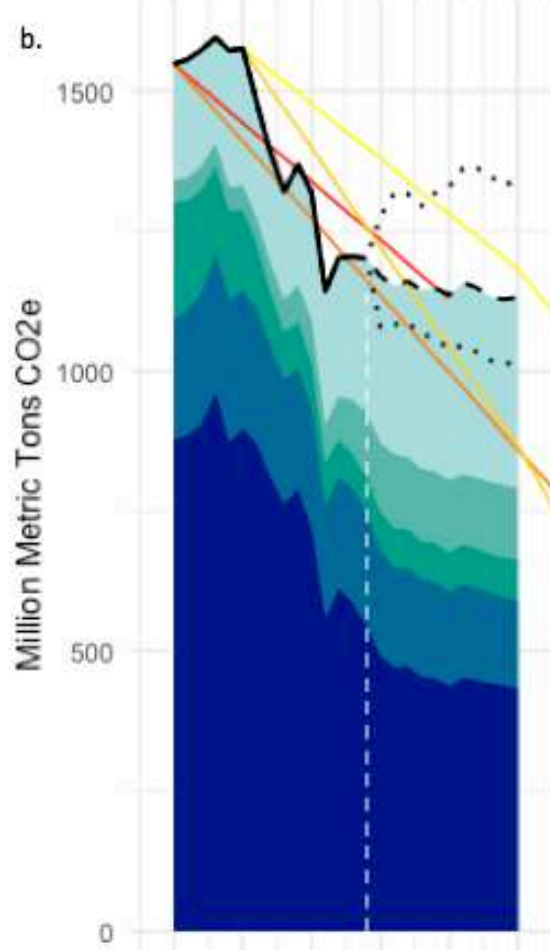

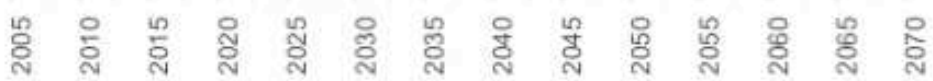

Figure 1. Production and emissions from fossil fuels produced on federal lands and waters. a. Shaded areas illustrate historic (2005 - 2019) and projected (2020 - 2030) fuel production on federal lands. b. Shaded areas show historic (2005 - 2019) and projected (2020 - 2030) emissions from fossil fuels produced on federal lands. Total projected emissions from coal, oil and gas are depicted for the mean output by the black dashed line. The dotted black lines represent the $95 \%$ confidence interval. Four climate targets are shown with linear reduction trajectories and baselines calibrated to total federal emissions. Targets include the US's Obama-era Nationally Determined Contribution (NDC) $[26-28 \%$ of 2005 by 2025]; Paris Climate Agreement $2^{\circ} \mathrm{C}$ goal ('Paris') [ $80 \%$ of 2005 by 2050]; IPCC's Special Assessment report's $1.5^{\circ} \mathrm{C}$ pathway $\left(1.5^{\circ} \mathrm{C}\right)$ [ $45 \%$ of 2010 by 2030 , net zero by 2050]; and IPCC's Special Assessment report's $2^{\circ} \mathrm{C}$ pathway $\left(2^{\circ} \mathrm{C}\right)$ [25\% of 2010 by 2030 , net zero by 2070 ].

Total federal lands emissions drop from 1,550 to 1,140 $\mathrm{MMTCO}_{2}$ e between 2005 and 2030. The majority of these emissions reductions occurred between 2005 and 2019. We project that emissions fall only $5.6 \%$ between 2019 and 2030, from 1,208 to 1,140

Coal emissions comprise the lion's share of historic emissions reductions, dropping by $334 \mathrm{MMTCO}_{2} \mathrm{e}$ or $38 \%$. Coal emissions are predicted to decrease by another $20 \%$ 
below 2019 by 2030, an additional $110 \mathrm{MMTCO}_{2} \mathrm{e}$. Projected onshore gas emissions decrease by $46 \mathrm{MMTCO}_{2} \mathrm{e}$, while offshore gas increases by nearly $9 \mathrm{MMTCO}_{2} \mathrm{e}$ in our projections. Federal oil emissions, which primarily come from vehicle exhaust, increase by a combined $78 \mathrm{MMTCO}_{2} \mathrm{e}$ in our model, nearly canceling out the bulk of federal fuel emissions reductions from the coal industry's projected decline. The annual cost to society - based on the social cost of carbon - of US federal fossil fuels between 2020 and 2030 range between $\$ 60$ to $\$ 76$ billion per year in 2020 dollars. Over the decade the aggregate costs range from $\$ 665$ to $\$ 840$ billion.

From a climate goal perspective, total federal fuel emissions will decline $26 \%$ below a 2005 baseline and $28 \%$ from a 2010 baseline by 2030. Our mean estimate for federal fossil fuel emissions has fallen adequately to play a commensurate role in meeting the least stringent, near-term trajectory of the $2^{\circ} \mathrm{C}$ goal established by the IPCC. However, the mean projections fall short of the more aggressive Paris and $1.5^{\circ} \mathrm{C}$ emissions reduction pathways, supporting earlier analysis (Ratledge et al. 2019). The lowest projections, shown by the lower dotted line in Figure 1b, also fail to meet the more aggressive climate ambitions on the 2030 timeline. Average federal fuel emissions estimates would need to decrease an additional 271 and $279 \mathrm{MMTCO}_{2} \mathrm{e}$ to meet linear trend lines for the $1.5^{\circ} \mathrm{C}$ and Paris goals.

The vast majority of the historic and projected emissions reductions were made between 2010 and 2016, when natural gas began rapidly replacing coal in the electricity sector and before unconventional oil development had begun to grow on federal lands. In essence, the low hanging fruit of federal lands emissions reductions have already occurred and were due to market trends. Without new policies or market shifts, our modeling predicts minimal additional gains in federal emissions reductions over the next ten years.

In total, our projections underscore the commonly held belief that reaching near zero emissions by 2050 will be challenging without additional policy interventions and more rapid clean technology deployment. This thesis is reinforced in the federal fuels case because some of the cheapest fuels in the US lie under federal lands, they are effectively subsidized with leasing and production fees that have not been updated in decades, and many already-leased parcels have ample future supply (US GAO 2019).

At the same time, the federal government - and the Office of the President - has the unique ability to aggressively reduce $\mathrm{CO}_{2}$ e emissions stemming from federal lands. The Department of the Interior has legal authority to employ a wide range of options - from reducing methane waste, instituting a lease buyback program and requiring mitigation measures at the drilling approval stage (Pleune et al. 2020) to adding a carbon fee on 
production from new coal, oil and gas leases (Gerarden et al. 2020; Krupnick et al. 2016; Prest 2020). If the US government is serious about leading on climate change mitigation, they should capitalize on the opportunity presented by overseeing energy management on federal lands and pursue many available authorities - including charging the full cost of development - to mitigate emissions from both existing leases and unleased land.

\section{Data and Methods}

We use publicly available data from the Office of Natural Resource Revenue to obtain coal, onshore oil, offshore oil, onshore gas and offshore gas production from 2005 to 2019 for federal lands and waters, not including American Indian and Tribal lands (ONRR 2020). We also gather production data from the Energy Information Administration's 2020 Annual Energy Outlook (AEO) Reference Case Scenario, which runs from 2020 to 2050 (US EIA 2020a).

The AEO provides projections for oil and gas production for offshore federal lands, but not onshore federal lands. To impute onshore production we combine historic data from ONRR with projected data from the AEO to create panel data. In total, we use 34 control variables and covariates to predict three output variables.

To impute federal onshore coal, oil and gas we use a regularized synthetic controls method introduced by Doudchenko and Imbens (2016), referred as synthetic controls with elastic net. This approach combines the traditional synthetic controls method, per Abadie (2010), with regularized regression. Mathematically,

$\widehat{Y_{J, T}}(0)=\widehat{\mu^{e n}}(j ; \alpha ; \lambda)+\sum \widehat{\omega_{l}^{e n}}(j ; \alpha ; \lambda) * Y_{i, T}^{o b s}$

where $\hat{Y}$ is the predicted value, $\hat{\mu}$ is the intercept, $\lambda$ is the penalty term, and $\alpha$ is how much weight to place on the Lasso and ridge term. $\omega$ is a weight for control observations, $Y_{i, T}^{o b s}$. Predicted values are optimized via,

$$
\operatorname{argmin}_{\mu, \omega} Q\left(\mu, \omega \mid Y_{t, p r e}^{o b s}, Y_{c, p r e}^{o b s}\right)=\left\|Y_{t, p r e}^{o b s}-\mu-\omega^{T} Y_{c, p r e}^{o b s}\right\|_{2}^{2}+\lambda \cdot\left(\frac{1-\alpha}{2}\|\omega\|_{2}^{2}+\|\omega\|_{2}\right)
$$

Essentially, each pre-period predicted variable is regressed separately on pre-period control variables and covariates, and penalized by an elastic net operator - providing coefficients for each control variable. These coefficients are applied to the post-period 
223 control variables and covariates to estimate the post period predicted variable in each

224 future year.

We use cross validation to test our model, wherein we randomly selected control variables and covariates and re-estimate held out 'predicted' variables in each bootstrap run. We focus our performance test on three similar control variables supplied in the EIA data - total US coal, oil and gas production, and predict their values from 2020 to 2030 . In 100 bootstrap samples per fuel type, we report a RMSE of .25, .68 and .49 respectively.

We apply this same randomly selected bootstrap approach to impute our three variables

We estimate associated lifecycle emissions of greenhouse gases (carbon dioxide, methane, and nitrous oxide) from federal lands (coal, onshore natural gas, offshore natural gas, onshore oil, and offshore oil) using calculation methods and assumptions employed by the EPA Inventory (US EPA 2020). To calculate downstream emissions we multiply production volumes by sector specific energy flows from EIA's Annual Energy Review (US EIA 2020b) and apply sector specific emission factors derived by multiplying average annual heat content by fuel type and consuming sector from EIA by EPA's emission factors by gas or carbon content coefficient by fuel type (US EPA 2018). To calculate upstream and midstream emissions, we scale down EPA's national-level, fuel- and segment-specific emissions data (US EPA 2020) using a ratio of federal production (ONRR 2020) to EIA national production (US EIA 2020b). Emission estimates weigh methane and nitrous oxide by their 100 -year global warming potential (IPPC 2007). Note that EPA revised its methane emissions methodology in 2019 to show a $1.1 \%$ leakage rate for the natural gas system, which is below top-down estimates of $2.36 \%$ (Alvarez et al. 2018).

We calculate the social cost of avoided emissions using the average annual per ton dollar value of avoided $\mathrm{CO}_{2}$ emissions established by the Interagency Working Group (IWG) on Social Cost of Greenhouse Gases under Executive Order 12866 (IWG 2016). We use the IWG annual global values and a central $3 \%$ average discount rate to account for the cost of climate impacts to future generations. All values are adjusted for inflation, applying a cumulative rate of inflation of $24.8 \%$ to adjust from 2007 to 2020 dollars. 
Abadie A, Diamond A, Hainmueller J (2010) Synthetic Control Methods for Comparative Case Studies: Estimating the Effect of California's Tobacco Control Program. Journal of the American Statistical Association.105, 490: 493-505 https://doi.org/10.1198/jasa.2009.ap08746

Alvarez R et al (2018) Assessment of methane emissions from the U.S. oil and gas supply chain. Science. 361, 6398: 186-88. http://doi.org/10.1126/science.aar7204

Doudchenko N, Imbens G (2016) Balancing, Regression, Difference-In-Differences and Synthetic Control Methods: A Synthesis. https://arxiv.org/abs/1610.07748.

Exec. Order No. 14008, 86 Fed. Reg. 7619 (January 27, 2021). Executive Order on Tackling the Climate Crisis at Home and Abroad. Sec 208. https://www.federalregister.gov/documents/2021/02/01/2021-02177/tackling-theclimate-crisis-at-home-and-abroad

Gerarden TD, Reeder WS, Stock JH (2020) Federal Coal Program Reform, the Clean Power Plan, and the Interaction of Upstream and Downstream Climate Policies. American Economic Journal: Economic Policy 12(1): 167-199 https://doi.org/10.1257/pol.20160246

Interagency Working Group on the Social Cost of Greenhouse Gases (2016) Technical Support Document: Technical Update of the Social Cost of Carbon for Regulatory Impact Analysis Under Executive Order 12866 (September 2016 Revision). Washington, DC: Interagency Working Group on the Social Cost of Carbon. https://obamawhitehouse.archives.gov/sites/default/files/omb/inforeg/august_2016_sc_c h4_sc_n2o_addendum_final_8_26_16.pdf

Intergovernmental Panel on Climate Change (2007) TS.2.5 Net Global Radiative Forcing, Global Warming Potentials and Patterns of Forcing. In Climate Change 2007: The Physical Science Basis. Contribution of Working Group I to the Fourth Assessment Report of the Intergovernmental Panel on Climate Change [Solomon, S., D. Qin, M. Manning, Z. Chen, M. Marquis, K.B. Averyt, M.Tignor and H.L. Miller (eds.)]. Cambridge University Press, Cambridge, United Kingdom and New York, NY, USA. https://archive.ipcc.ch/publications_and_data/ar4/wg1/en/tssts-2-5.html

Krupnick A, Darmstadter J, Richardson N, McLaughlin K (2016) Putting a Carbon Charge on Federal Coal: Legal and Economic Issues. The Environmental Law Reporter. ELR 20572. 46(7) https://elr.info/news-analysis/46/20572/putting-carbon-chargefederal-coal-legal-and-economic-issues 
Leshy JD (2019) Interior's Authority to Curb Fossil Fuel Leasing. Environmental Law Reporter, 49: 10631 https://elr.info/news-analysis/49/10631/interiors-authority-curbfossil-fuel-leasing

Merrill MD et al (2018) Federal Lands Greenhouse Emissions and Sequestration in the United States - Estimates for 2005-14: US Geological Survey Scientific Investigations Report 2018-5131. https://doi.org/10.3133/sir20185131

Oliver J, Peters J (2020) Trends in Global CO2 and Total Greenhouse Gas Emissions; 2019 report. PBL Netherlands Environmental Assessment Agency.

https://www.pbl.nl/sites/default/files/downloads/pbl-2020-trends-in-global-co2-and-totalgreenhouse-gas-emissions-2019-report 4068.pdf

Pleune JG, Ruple JC, Culver NW (2020) A Road Map to Net-Zero Emissions for Fossil Fuel Development on Public Lands. ENVTL. L. REPORTER NEWS \& ANALYSIS 50: 10734-43. https://www.eli.org/sites/default/files/docs/elr pdf/50.10734.pdf

Prest B (2020) Supply-side reforms to oil and gas production on federal lands: Modeling the implications for climate emissions, revenues, and production shifts. Resources for the Future. Working Paper 20-16. https://www.rff.org/documents/2628/RFF WP 2016 Prest.pdf

Ratledge N, Davis SJ, Zachary L (2019) Public lands fly under climate radar. Nature Climate Change, 9:89-93. https://www.nature.com/articles/s41558-019-0399-

7.pdf?proof $=\mathrm{t}$

Rogelj $\mathrm{J}$ et al (2018) Mitigation Pathways Compatible with $1.5^{\circ} \mathrm{C}$ in the Context of Sustainable Development. In: Special Report on Global Warming of $1.5^{\circ} \mathrm{C}$.

Intergovernmental Panel on Climate Change, 93-174

https://www.ipcc.ch/sr15/chapter/chapter-2/

US Bureau of Land Management (2020) Public Land Statistics 2019. US Department of the Interior. https://www.blm.gov/sites/blm.gov/files/PublicLandStatistics2019.pdf

US Bureau of Ocean Energy Management (2020) About BOEM Fact Sheet. US Department of the Interior. http://www.boem.gov/about-boem/boem-fact-sheet

US Energy Information Administration (EIA) (2020a) Annual Energy Outlook 2020. https://www.eia.gov/outlooks/aeo/

US EIA (2020b) Annual Energy Review. https://www.eia.gov/totalenergy/data/annual/ 
342 US Environmental Protection Agency (2020) Inventory of US Greenhouse Gas

343 Emissions and Sinks:1990-2018. US EPA 430-R-20-002.

344 https://www.epa.gov/ghgemissions/inventory-us-greenhouse-gas-emissions-and-sinks

US EPA (2018) EPA emission factors for greenhouse gas inventories. Modified 9 March

347 2018. https://www.epa.gov/sites/production/files/2018-03/documents/emission-

348 factors mar 2018 0.pdf

US Government Accountability Office (2019) Challenges to Ensuring a Fair Return for Federal Energy Resources. GAO, 19-718T. https://www.gao.gov/assets/710/701616.pdf

US Office of Natural Resources Revenue (2020) Calendar year production data (20052019). US Department of the Interior, ONRR. 


\section{Figures}

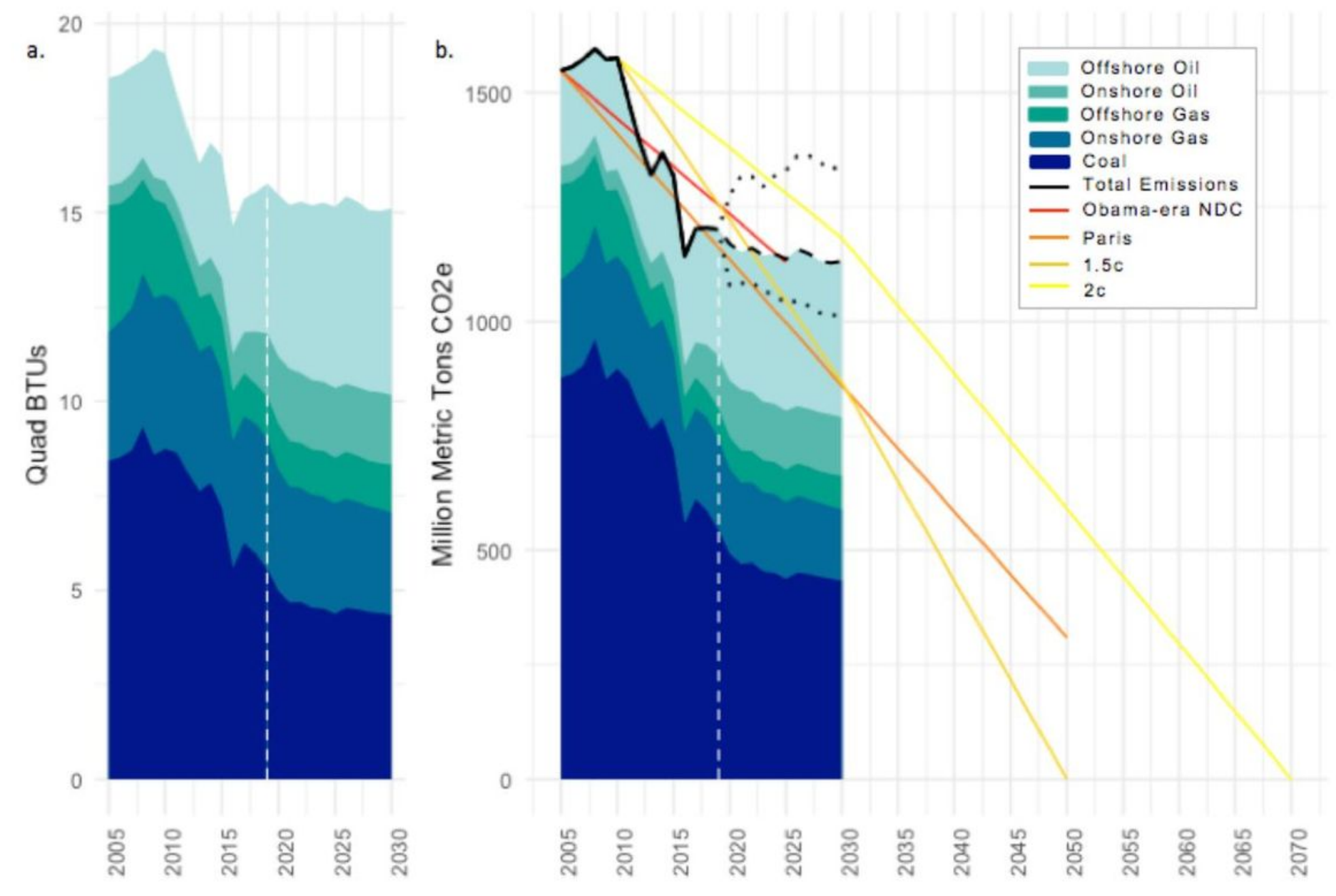

\section{Figure 1}

Production and emissions from fossil fuels produced on federal lands and waters. a. Shaded areas illustrate historic (2005 - 2019) and projected (2020 - 2030) fuel production on federal lands. b. Shaded areas show historic (2005 - 2019) and projected (2020 - 2030) emissions from fossil fuels produced on federal lands. Total projected emissions from coal, oil and gas are depicted for the mean output by the black dashed line. The dotted black lines represent the $95 \%$ confidence interval. Four climate targets are shown with linear reduction trajectories and baselines calibrated to total federal emissions. Targets include the US's Obama-era Nationally Determined Contribution (NDC) [26-28\% of 2005 by 2025]; Paris Climate Agreement $2^{\circ} \mathrm{C}$ goal ('Paris') [80\% of 2005 by 2050]; IPCC's Special Assessment report's $1.5^{\circ} \mathrm{C}$ pathway $\left(1.5^{\circ} \mathrm{C}\right)$ [ $45 \%$ of 2010 by 2030 , net zero by 2050]; and IPCC's Special Assessment report's $2^{\circ} \mathrm{C}$ pathway $\left(2^{\circ} \mathrm{C}\right)[25 \%$ of 2010 by 2030 , net zero by 2070$]$. 